\title{
For Fate and Fortune: American Privateers in the War of 1812
}

By Brandon Harrison

The Wolf and the Pike

(sung to the tune of "The Cobbler")

A Wolf once met a Pike, And vow'd that he would eat her,

Did you e'er dream the like;

That little Pike should beat her;

Says Wolf I'm tir'd of beef and veal,

And fish is finer feeding,

But little Pike with fins of steel,

Set her great mouth a bleeding.

When Wolf first felt her wound,

She scamper'd up from the table,

And ran upon dry ground,

As fast as she was able;

Says she this was a cursed dish,

For Wolf to think of ever,

And Pike from this day is a fish

I ne'er will taste - no never.

But Pike, who from the deep,

With scorn beheld her canting;

Now feigns to be asleep,

And for more sport is panting.

If ugly Wolf invade her bed of water,

The pretty Pike will strike her dead,

Unless she cry for quarter. ${ }^{l}$

Compared to the British Royal Navy, the Americans in the War of 1812 appeared to have no hope of victory. Yet, just like the Pike, American privateers and letter-of-marques sent the British away, battered and bruised. During the War of 1812, these privately armed vessels (totaling five hundred and twenty-six by the end of the war) managed to capture between 1,1752,300 enemy ships - doing over forty million dollars worth of damage to British commerce and bringing a total of $\$ 10,676,793.50$ into the American economy. ${ }^{2}$ Unfortunately, this success did not come without cost. Countless men lost life and fortune by taking to the sea as privateers and letter-of-marques. ${ }^{3}$ Therefore, the question arises as to why these men would engage in such a perilous activity? For historians, the idea of patriotism-serving to protect one's beloved country - has often been proposed as the answer to this question. This paper, however, revisits this motivation. It demonstrates that patriotism only speaks to a select few aboard America's 
privately armed vessels. Instead, money - the idea of becoming rich-proves to be the true motivation behind the vast majority of these men.

Over the years, many historians have debated the motivations propelling privateers and letter-of-marques to engage in these potentially life-threatening wartime activities. Some, according to Andrew Lambert, attempt to portray privateers as patriotic men, whose deep love for their country motivated them to take up arms against the British. ${ }^{4}$ This is a fair conclusion considering the amount of romanticism that surrounds the topic. Republicans long portrayed a rather patriotic image of these men, dubbing them "the militia of the sea." ${ }^{5}$ Occasionally, men did in fact prove to be motivated by their patriotism. Men like Joshua Barney, for example, a veteran of the American Revolution, eagerly answered the call to arms as a patriot, ready to once again serve his beloved country. ${ }^{6}$ Yet, although men like Barney did exist, not all men could claim such patriotic motivations. Many privateers committed crimes against the United States, often in the form of illegal trade with Britain. ${ }^{7}$ Thus, one cannot say that all men found themselves motivated by patriotism. Instead, one must look to a far simpler answer: money. Although privateering offered men a chance to contribute to America's war effort, it was first and foremost a business venture. Privateering offered men the chance to make fortunes, and this proved to be a powerful motivator by the time war broke out in $1812 .^{8}$ Even Thomas Jefferson, after suggesting the need to encourage privateering in the United States commented, "We have tens of thousands of seamen that without it would be destitute of the means to support [themselves], and useless to their country." 9

By the time war broke out in 1812, privateering was no new concept. For centuries, countries used the commission to control merchantmen seeking revenge for damaged or stolen property. It offered these men a chance to take action, at their own expense of course, against the nation or individual who had wronged them. ${ }^{10}$ The role of a privateer evolved in Elizabethan England. During the fabled 'Age of Exploration,' privateers not only became the major financiers of New World exploration, they became the primary agents of it as well. ${ }^{11}$ Men like Sir Francis Drake and Sir Walter Raleigh are just some of the most famous Elizabethan privateers. These men are remembered for their spectacular adventures on the high seas. ${ }^{12}$ Even for the young American government, privateering was no new concept. During the American Revolution, the infant government enlisted the support of approximately seven hundred privately owned and armed vessels. They represented a fundamental part of the American naval effort with Benjamin Franklin even going so far as to recruit the added support of French privateers. ${ }^{13}$ 
Not only did they provide a steady and fairly effective threat to enemy commerce, they also provided a steady influx of British prisoners. These prisoners could then be ransomed for American ones as needed. ${ }^{14}$

After playing such a critical role in the American Revolution, it is understandable that the American government once again eagerly employed privateers at the start of the War of 1812 . Following the declaration of war against Great Britain, President Madison wasted little time enlisting the help of privateers and letter-of-marques. The President placed little faith in the American navy. After all, it only consisted of twenty man-o-wars, seven of which, including the famous USS Chesapeake, could be found sitting in American ports undergoing extensive repairs. ${ }^{15}$ In comparison, the Royal Navy boasted a force in excess of a thousand ships, six hundred of which could be found at sea at any given time. ${ }^{16}$ Now admittedly, many of the Royal Navy's ships found themselves engaged in activities in and around Europe, but even the Halifax fleet posed a formidable force. With a sixty-four gun man-o-war (sometimes referred to as shipof-the-line), five frigates, eleven sloops, and a mixture of six miscellaneous smaller vessels, the Halifax fleet represented a far more formidable force than anything the United States Navy could muster. ${ }^{17}$ Fortunately for the American government, men would eagerly step forth as privateers and letter-of-marques.

When news of an impending war reached the ears of James De Wolf, a leading merchant in the town of Bristol, he wasted little time outfitting a ship to be used as a privateer. ${ }^{18}$ De Wolf was just one of a number of merchantmen who suffered losses at the hands of the British. Thus, when the declaration of war between the United States and Great Britain became official, he quickly requested a commission:

The Honorable William Eustis,

Bristol, R. I., June 30, 1812.

Secretary of War:-

Sir; I have purchased and now ready for sea, an armed brig, (one of the most suitable in this country for a privateer) of one hundred and sixty tons burden, mounting eighteen guns, and carries one hundred and twenty men, called the Yankee, commanded by Oliver Wilson. Being desirous that she should be on her cruise as soon as possible, I beg that you will cause a commission to be forwarded as soon as practicable to the Collector of the District, that this vessel may not be detained.

I am very respectfully, Sir,

Your obedient servant,

James De Wolf ${ }^{19}$ 
As President Madison predicted, hundreds of men like De Wolf turned out at the start of the war to eagerly offer their services as privateers. Like De Wolf, these men brought an array of powerful ships and an abundance of valuable resources. ${ }^{20}$ Although Madison was eager to accept their offers, he was not ready to give them the freedom to operate however they wished. Instead, he set about implementing a strict set of rules and regulations. ${ }^{21}$

During the American Revolution, privateers gained commissions from their home states and operated with little, if any control. ${ }^{22}$ Madison refused to see this pattern play out in the War of 1812 and demanded the strict regulation of all American privateers and letter-of-marques. Thus, unlike pirates, privateers and letter-of-marques found themselves bound by a strict set of wartime rules and regulations. ${ }^{23}$ Any ship owner could apply for a commission, provided that he was an American citizen. He simply had to provide two sureties - individuals willing to sign a five to ten thousand dollar bond ensuring that the new privateer would follow all regulations set forth by the American government. ${ }^{24}$ Regardless of the commission, these regulations all shared the same features. Sailors needed "to proceed, in exercising the rights of war, with all the justice and humanity which characterize the nation." ${ }^{25}$ Moreover, they could not, unless given due reason to suspect involvement with the enemy, 'molest' the vessels of a neutral power. ${ }^{26}$ Accepting these conditions, ship-owners would submit their applications to the secretary of state and wait for Congress (and President Madison as his signature was required on each commission) to grant their request. ${ }^{27}$ Any privateers or letter-of-marques found operating without such a document would be treated, along with their crews, as pirates subject to the full extent of the capturing country's law - in most cases this meant death by hanging. ${ }^{28}$

Once granted a commission, owners accepted all the costs and risks associated with the venture. This included the outfitting of ships with guns and supplies. Fully outfitted, the average ship cost anywhere from $\$ 20,000$ to $\$ 40,000 .^{29}$ In addition, owners would have to feed crews of about 100 to 150 men for the duration of the voyage. ${ }^{30}$ They did not, however, have to pay the men any set salary. Instead, men received payment based on the prizes captured by the ship and how much revenue they brought at auction. In the case of failure, these men could spend months at sea without receiving a penny for their efforts. ${ }^{31}$ Moreover, in the case of a particularly catastrophic voyage, these men could find themselves imprisoned while the owners found themselves at a complete loss, both of ship and profit. ${ }^{32}$ With such great costs, why would anyone, ship owner or sailor alike, want to risk engaging in such a dangerous activity? 
By the time war broke out in 1812, the United States found itself in the midst of a crippling depression. ${ }^{33}$ Despite their neutrality, the United States failed to avoid the repercussions of Napoleon's war in Europe. When it began, American merchantmen made handsome profits trading to both sides. ${ }^{34}$ By 1807 however, this took a drastic turn. The United States government began issuing a series of laws aimed at damaging British and French trade. ${ }^{35}$ Unfortunately for the Americans, they grossly miscalculated the effect such laws would have on their own economy. By December, American merchantmen found themselves under a complete non-exportation law. Domestic ships, as well as merchandise, were prohibited from leaving home ports. ${ }^{36}$ Luckily for American merchantmen, this early policy was riddled with loop holes just waiting to be exploited. Despite the restrictions, many merchant vessels continued work abroad. They managed to sneak out of port just prior to the law, and they had no intentions of returning home. Instead, they stayed at sea, trading between foreign ports and giving their owners a steady supply of profit. ${ }^{37}$

In 1809, this quasi-legal trade came to an abrupt halt. Tired of smuggling and still believing it could cripple European economies, Congress gave customs officials absolute power over all merchant shipping. Now, customs officials could use America's military forces (both on land and at sea) to enforce the embargo. ${ }^{38}$ For Americans, this came as unwelcomed news. Prices were already at an all-time low as farmers could find no way, legally or illegally, of selling surplus crops to foreign markets. At the same time, merchants watched as their ships rotted in port, and American exports plummeted from 108 million dollars in 1807 to less than 22 million dollars in $1809 .^{39}$

Realizing the dire state of their country's economy, Congress quickly repealed the embargo by March of 1809. They then replaced it with one directed specifically at British and French commerce. ${ }^{40}$ This came as a welcomed reprieve for Americans as merchants could once again trade (albeit illegally) with their British partners. Baltimore itself became a major business hub for both legal and illegal activities. Despite the persistence of a small group of patriotic merchants, almost all of the city's merchant ship-owners began trading grain products illegally with the British. ${ }^{41}$ Even after Madison's 1811 non-importation law against Great Britain, Baltimore merchants, like many others, continued to supply the British - effectively turning a potentially prosperous trade route into an exclusive accumulation of material wealth in Great Britain. ${ }^{42}$ In the end, it is evident that treasonous behaviour became something of a norm amongst American merchantmen wishing to earn profits. As a result, it is of little surprise that 
patriotism must be seriously questioned as the motivation propelling men to engage in privateering.

With America in the midst of a crippling economic depression, merchant ship-owners found themselves with few options when the War of 1812 broke out. On the one hand, they could do nothing and watch their ships once again rot in port while they slowly descended into complete bankruptcy. ${ }^{43}$ On the other hand, however, they could be proactive. Ship-owners could outfit their ship(s) with the necessary armaments and make good use of the legal framework of war. They could become privateers or letter-of-marques and possibly make fortunes at sea. ${ }^{44}$ Considering the overall lack of alternative ventures, the prospects of a prize and the profit it offered proved more than enough for most would-be privateers. ${ }^{45}$ This was especially true considering ship owners earned approximately half of whatever the ship's prize sold for at auction (if a ship had multiple owners, as was common, then this sum would be divided amongst them). ${ }^{46}$

As the war dragged on, profit became increasingly important for ship-owners and investors alike. Not only was it their motivation for enrolling in the increasingly dangerous activity, it was also their motivation for remaining in it. As a result, privateers like John Ferguson and John Lawrence quickly began petitioning Congress to improve the profitability of the activity by reducing costs such as customs duties. ${ }^{47}$

At the start of the war, customs duties varied for each prize. Generally, they amounted to approximately half the total value of a prize once sold. These duties would go towards a number of different expenses including court costs, lawyers, and even benevolent funds such as the Seamen's Hospital Fund. ${ }^{48}$ The amount left over was the privateer's profit. In the case of the privateer Teazer and its prize Venus, the prize sold at auction for a respectable $\$ 17,637.68 .^{49}$ Duties on this prize amounted to a staggering $\$ 8,287.63$, or $47 \%$ of the total value, leaving only $\$ 9,350.05$ to be divvied up between owners and crew. ${ }^{50}$ With such a drastic cut out of their profit, it is of little wonder why money-minded privateers began to protest. The owners of the Teazer even went so far as to inform Congress that failure to reduce the crippling duties would see them remove their vessel from active service. ${ }^{51}$ Luckily for them, Congress did eventually decide to reduce the customs duties on 27 July $1813 .{ }^{52}$ The vote came just five days after Congress reviewed a letter written by Hugh Nelson, Chairman of the Naval Committee. Originally addressed to William Jones, the acting Secretary of the Treasury, the letter reviewed 
the case in favour of granting privateers a reprieve from heavy taxation. In it, Nelson explained the situation quite plainly:

The fact is, that, from causes that occupy the present discussion, privateering is nearly at an end; and, from the best observation I have been enabled to make, it is more from the deficiency of remuneration in the net proceeds of their prizes, than from the vigilance and success of the enemy in recapturing. ${ }^{53}$

Realizing the truth in Nelson's words, Congress voted sixty-nine to thirty-seven in favour of reducing the duties placed on captured prizes. This, they hoped, would provide privateers with the monetary encouragement they demanded to continue their fight against British commerce. ${ }^{54}$

Although it is evident that ship-owners and investors alike gravitated towards privateering for the sake of money, they were not the only ones. Average sailors from across the country flocked towards privateers and letter-of-marques as they offered the chance to earn a much-needed income. ${ }^{55}$ Many of these men found themselves bearing the full brunt of the economic depression. Noah Jones (or Johnson), the man often associated with the pen name "A Wanderer," understood this situation all too well. In his second journal aboard the privateer Yankee, he reflects on the economic state of America in October of 1812 - admitting that he, like many of his shipmates, could not afford to waste an opportunity for profit, especially with the coming of winter. ${ }^{56}$ John Lord, the man whose experiences are recorded in the Yarn of a Yankee Privateer, expressed a similar sentiment after watching countless young men, one after the other, board privateers, drawn by the allure of money. Lord even recounted how his own crewmates eagerly looked on as they approached a potential prize, avariciously trying to determine the potential value of their own share(s). ${ }^{57}$ According to Lord, the division of these shares could be broken down like this:

\section{Crewmember's Rank}

Captain

Lieutenants, Sailing Master(s)

Prize Master, Master's Mates

Boat Swain, Gunner, Carpenter

Able Seamen

Landsmen, Boys

\section{Standard division of Prize Shares}

$$
\begin{gathered}
8-10 \\
5-6 \\
3-4 \\
21 / 2-3 \\
1 \\
1 / 2-3 / 4
\end{gathered}
$$

Source: Browne, The Yarn of a Yankee Privateer, 48. 
Although the division of shares obviously favoured the upper echelon of a ship's crew, even the lowliest members stood to gain a profit in the event of a successful capture. As a result, it is understandable that many men would find such prospects both appealing and motivating. Yet, understanding share quantities is not enough. One must also look to the value of such shares, and for this, one must analyze individual ships like the Yankee.

Owned by James De Wolf and John Smith, the privateer Yankee is one of the most renowned privateers of the War of 1812. Its career beautifully illustrates the power money possessed to motivate these men to engage in such a dangerous activity. On 15 October 1812, the Yankee made its maiden voyage out of Bristol with 18 guns and a crew of ninety-five 'prime fellows. ${ }^{15}$ After 146 days at sea, the ship returned to harbour with each individual share amounting to approximately $\$ 700.00 .{ }^{59}$ Hearing word of the astonishing fortune made by the men of this first voyage, sailors could hardly wait for the Yankee to set sail again. When the time came, men practically fought one another for a place onboard its deck. ${ }^{60}$ Although the second voyage did not bring the same fantastical results, each share still amounted to a remarkable $\$ 338.40 .{ }^{61}$ Shares from the third voyages declined further, dropping to $\$ 173.54$ per share. ${ }^{62}$ Unfortunately, though, the Yankee's fourth voyage failed to reap such results. With only two minuscule prizes able to safely reach port without being recaptured, each share amounted to a meagre $\$ 17.29$ - still a profit, but nowhere near the profit men had seen on previous voyages. ${ }^{63}$ As the value of shares declined, so too did the number of eager sailors hungry for profit. As the Yankee prepared for its fifth voyage, most sailors believed the trip would be a bust. Unlike its previous voyages, men could easily find space aboard the aging privateer. Some men, foreseeing an unrewarding voyage, even decided to jump-ship as the privateer made its way out of port. ${ }^{64}$ Ironically, this voyage proved to be the most profitable for the Yankee. Not only did the ship's owners receive an incredible $\$ 223,313.10$, but its lowliest crewmember, a sailor of colour, received $\$ 738.19$. As for the rest of the crew, they cleared profits in excess of $\$ 1,100.00$ with the Captain earning a staggering $\$ 15,789.69 .{ }^{65}$ As one can imagine, tale of such profits was more than enough to ensure an ample crew for the sixth and final voyage of the Yankee. The case of the Yankee itself beautifully illustrates just how motivational money could be for would-be privateers. In saying this, however, the Yankee was but one privateer amongst many. To better understand the situation, one must understand the profitability of this perilous activity.

When scouring through newspapers like the Boston Patriot, a plethora of notices can be found relating to the prizes and auctions of privateers. Unfortunately, many of these articles fail 
to state the actual value of these prizes. Despite this omission, these articles can still provide valuable information concerning the number of vessels returning to American harbours, as well as the products they contained. On 24 October 1812, the 260-ton ship named Guyana appeared in the Boston Patriot. The vessel boasted eight cannons and a cargo consisting of salt (250 tons), coal (30 tons), and 160 crates of miscellaneous wares. ${ }^{66}$ Although the article fails to mention a value, it is evident simply by the ship and its contents that profit was to be made. Yet, such an assumption does little to satisfy the quantitatively-minded historian, thus one must dig further combing newspapers with ship's logs and journals.

When discussing profit, one is inclined to go specifically, and often exclusively, to the privateer Yankee. This, however, was not the only privately armed ship that proved profitable. In 1813, a letter-of-marque by the name of Argus managed to return to its home port of Boston with a prize ship laden with 16,000 hides, valued at $\$ 160,000$. It also carried $\$ 20,000$ worth of merchandise within its own hull, which it promptly sold after returning home. ${ }^{67}$ In 1814 , upon completing its third voyage, the America recorded 12 prizes bringing its grand total to 26, amounting to a value of approximately $\$ 1,100,000 .{ }^{68}$ Even when things went wrong, profit could still be made. In 1813, while patrolling the English shipping lines, the Leo, a letter-of-marque captained by Captain $T$. Lewis managed to capture a British East India ship valued at approximately $£ 500,000$ sterling. ${ }^{69}$ Although the English eventually recaptured the ship while it sailed for American shores, Captain Lewis still managed to make a profit of approximately $\$ 60,000$ after having transferred the prize's most valuable cargo over to his own ship. ${ }^{70}$ On average, privateers in the War of 1812 took two to three ships. This meant that on a typical cruise, a sailor, regardless of his status onboard the ship, could earn a profit in the neighborhood of three hundred dollars. ${ }^{71}$ For three months (or less) worth of work, not only was this three to four times greater than the average sailor's pay, it was also an enticing reason to engage in this activity. $^{72}$

Despite the profitable nature of privateering, one must understand that not all voyages ended in success. ${ }^{73}$ Numerous voyages ended with ships returning to port without a prize despite previous success. Over the course of the war, approximately seven hundred and fifty American prizes failed to arrive at American ports after being recaptured, often by British warships. ${ }^{74}$ Others however, like the Bona and the Blockade, failed to capture any vessel at all. Ships like these are part of a larger group, comprising $42 \%$ of privateers and letter-of-marques - who, despite their valiant attempts, failed to make profits exceeding $\$ 50,000 .^{75}$ Despite the chance of 
failure, the possibility of earning a fortune proved to be more than enough motivation for these men. Even after the war, many men chose to continue their operations in hopes of making a greater fortune at sea.

After the war, many men chose to return to their agrarian lifestyles, once again diligently working the land to earn a living. Some men, however, could not turn their backs to the sea or the profitability of privateering. Few professions, both on land and at sea, could compare to the money one could make as a privateer. ${ }^{76}$ Unfortunately, though, peace meant that the United States no longer required privateers or letter-of-marques. ${ }^{77}$ Once again motivated by the prospect of wealth, former privateers quickly became pirates despite the risk it posed to one's life if arrested. ${ }^{78}$ Most of these men made their way to the Caribbean where they began looting unsuspecting vessels. ${ }^{79}$ Although the risk was death if caught, the prizes could potentially be far greater as they no longer had customs duties or owners to pay. ${ }^{80}$

In the end, it becomes apparent that American privateers found motivation in the wealth this occupation appeared to offer. With the United States in the midst of an economic depression, privateering offered these men the potential to earn a living. Moreover, it offered the potential for an individual, if he was willing to accept the risks, to earn an income three to four times greater than that of any labourer. In some of the most extraordinary cases, men could make anywhere from $\$ 700.00$ to $\$ 15,000$ in a single voyage. Thus, it is of little wonder why they eagerly applied for employment aboard these ships. Even when the war ended and the activity became known as the illegal act of piracy, men still found motivation in the fortunes it offered. For all privateers, both owners and crew, motivation could be summarized in the simple adieu of the Yankee's 'Wander,' "Farewell, ye tranquil pleasures of social life! I sacrifice ye all at the imperious calls of Fate and Fortune."

\section{NOTES}

${ }^{1}$ Robert Malcomson, Lords of the Lake: The Naval War on Lake Ontario 1812-1814 (Quebec: Robin Brass Studio, 2001), 225.

2 George C. Daughan, 1812: The Navy's War, (New York: Basic Books, 2011), 323; Frederick C. Leiner, "Privateers and Profit in the War of 1812," Journal Of Military History 77, no. 4 (October 2013): 1231; Alexander Tabarrok, "The Rise, Fall and Rise Again of Privateers," Independent Review no. 4 (2007): 571.

${ }^{3}$ Although this paper will be discussing privateers and letter-of-marques simultaneously, it should be understood that the two are different from one another. Privateers are privately armed vessels designed specifically for privateering work. While at sea, a privateer's sole responsibility is to attack enemy commerce. Letter-ofmarques on the other hand are former merchant ships equipped with arms so that they may take an enemy vessel if the opportunity presents itself. They, however, remain primarily merchant vessels and continue to 
trade with neutral countries. For more information refer to Stephen Budiansky, Perilous Fight: America's Intrepid War with Britain on the High Seas, 1812-1815 (New York: Alfred A. Knopf, 2010), 287.

${ }^{4}$ Andrew Lambert, The Challenge: America, Britain and the War of 1812 (London: Faber and Faber, 2012), 201.

${ }^{5}$ Budiansky, Perilous Fight, 286.

${ }^{6}$ Lambert, The Challenge, 73-74.

${ }^{7}$ Ibid., 199-200.

${ }^{8}$ Leiner, "Privateers and Profit in the War of 1812," 1225, 1230.

${ }^{9}$ George Coggeshall, History of the American privateers, and letters-of-Marque, during our war with England in the years 1812, '13, and '14, interspersed with several naval battles between American and British ships-of-war (New York: Published by and for the Author, 1856), xliv.

${ }^{10}$ Tabarrok, "The Rise, Fall and Rise Again of Privateers."

${ }^{11}$ Ibid., 566.

${ }^{12}$ Ibid.

${ }^{13}$ Ibid., 567.

${ }^{14}$ Ibid.

${ }^{15}$ Daughan, 1812: The Navy's War, 31-39.

${ }^{16}$ Ibid., 39.

${ }^{17}$ Ibid., 40 .

${ }^{18}$ Wilfred Harold Munro, "The Most Successful American Privateer," Proceedings Of The American Antiquarian Society 23, no. 1 (April 1913): 12-13.

${ }^{19}$ Munro, "The Most Successful American Privateer," 13.

${ }^{20}$ Daughan, 1812: The Navy's War, 147.

${ }^{21}$ Ibid.

${ }^{22}$ Ibid.

${ }^{23}$ Ibid.

${ }^{24}$ Budiansky, Perilous Fight, 287.

${ }^{25}$ James Monroe, Letter of Marque, ca. 1812.

${ }^{26}$ Ibid.

${ }^{27}$ Daughan, 1812: The Navy's War, 147.

${ }^{28}$ Ibid.

${ }^{29}$ Leiner, "Privateers and Profit in the War of 1812," 1232.

${ }^{30}$ Budiansky, Perilous Fight, 288; Leiner, "Privateers and Profit in the War of 1812," 1232.

${ }^{31}$ Ibid., 288-289.

${ }^{32}$ Lambert, The Challenge, 73-74.

${ }^{33}$ Donald R. Hickey, The War of 1812: A Forgotten Conflict (Urbana: University of Illinois Press, Revised Edition, 2012), 20.

${ }^{34}$ Ibid., 19-20; Lambert, The Challenge, 199-200.

${ }^{35}$ Hickey, The War of 1812, 18-19.

${ }^{36}$ Ibid.

${ }^{37}$ Ibid., 19.

${ }^{38}$ Ibid., 20.

${ }^{39} \mathrm{Ibid}$.

${ }^{40}$ Ibid.

${ }^{41}$ Lambert, The Challenge, 199-201.

${ }^{42}$ Ibid., 201; Hickey, The War of 1812, 21.

${ }^{43}$ Leiner, "Privateers and Profit in the War of 1812": 1230; Nicholas J. Ross, "The Provision of Naval Defense in the Early American Republic: A Comparison of the U.S. Navy and Privateers, 1789-1815," Independent Review 16, no. 3 (Winter 2012): 420-421.

${ }^{44}$ Ross, "The Provision of Naval Defense in the Early American Republic," 420-421.

${ }^{45}$ Lambert, The Challenge, 200.

${ }^{46}$ Benjamin Frederick Browne, The Yarn of a Yankee Privateer, ed. Nathaniel Hawthorne (New York: Funk \& Wagnalls Company, 1926), 48.

${ }^{47}$ Leiner, "Privateers and Profit in the War of 1812," 1235.

${ }^{48}$ Ibid., 1232.

${ }^{49}$ Ibid., 1235. 
${ }^{50}$ Ibid.

${ }^{51}$ Ibid., 1235-1236.

${ }^{52}$ Ibid., 1245-1247; Annals of Congress, 13th Congress, 1st Session: 479.

53 Annals of Congress, 475.

${ }^{54}$ Leiner, "Privateers and Profit in the War of 1812," 1245-1247; Annals of Congress, 473-479.

${ }^{55}$ Lambert, The Challenge, 200; Budiansky, Perilous Fight, 287.

${ }^{56}$ A Wanderer, Journals of Two Cruises Aboard the American Privateer Yankee, ed. Noah Jones (New York: MacMillan, 1967), 62-63.

${ }^{57}$ Browne, The Yarn of a Yankee Privateer, 3-5.

${ }^{58}$ Munro, "The Most Successful American Privateer," 19.

59 Ibid., 59, 16.

${ }^{60}$ Ibid., 16.

${ }^{61}$ Ibid.

62 Ibid., 17.

${ }^{63}$ Ibid.

${ }^{64}$ Ibid., 17-18

${ }^{65}$ Ibid., 18.

${ }^{66}$ J. Prince, "Marshal's Notice. Prize Ship and Cargo," Boston Patriot (Boston, MA), Oct. 24, $1812,3$.

${ }^{67}$ Coggeshall, History of the American Privateers, 149-150.

${ }^{68}$ Ibid., 227.

${ }^{69}$ Ibid., 147.

${ }^{70}$ Ibid.

${ }^{71}$ Budiansky, Perilous Fight, 289.

72 Ibid.

${ }^{73}$ Lambert, The Challenge, 73-74.

${ }^{74}$ Ibid., 205.

75 Timothy S. Good, American Privateers in the War of 1812: the vessels and their prizes as recorded in Niles' Weekly Register (Jefferson, N.C.: McFarland \& Co., 2012), 21; Lambert, The Challenge, 209.

${ }^{76}$ John A. Tures, "A Word of 'Captain Caution': Myths About Privateers in the War of 1812," The War of 1812 Magazine 14 (October 2010), available at http://www.napoleon-

77 Ibid. series.org/military/Warof1812/2010/Issue14/c_Privateers.html

${ }^{78}$ Ibid.

${ }^{79}$ Ibid.

${ }^{80}$ Ibid. 